\title{
A study on the effects of subsidies on market value: Evidence from Petrochemical and steel industries
}

\author{
Batool Norouzi ${ }^{\mathrm{a}}$ and Mohsen Hamidian ${ }^{\mathrm{b}}$
}

${ }^{a}$ Department of management and Accounting, South Tehran Branch, Islamic Azad University, Tehran, Iran ${ }^{b}$ Faculty member, Department of management and Accounting, South Tehran Branch, Islamic Azad University, Tehran, Iran

\begin{tabular}{|c|c|}
\hline C H R O N I C L E & A B S T R A C T \\
\hline $\begin{array}{l}\text { Article history: } \\
\text { Received October 28, } 2014 \\
\text { Received in revised format } 2 \\
\text { February } 2015 \\
\text { Accepted } 4 \text { February } 2015 \\
\text { Available online } \\
\text { February } 42015 \\
\text { Keywords: } \\
\text { Tehran Stock Exchange } \\
\text { Subsidy removal }\end{array}$ & $\begin{array}{l}\text { Iran's } 4^{\text {th }} \text { development plan has enrolled the federal government to increase energy prices and } \\
\text { remove any subsidies paid to energy sector in an attempt to increase productivity and provide } \\
\text { better social welfare. It is, therefore, important to investigate the effects of the law on different } \\
\text { industries and the subsequent effects on economic growth. This study investigates the impacts } \\
\text { of subsidies on the market value of listed companies in Tehran Stock Exchange in } \\
\text { Petrochemical and Steel industries. The study selects two firms, Esfahan's Mobarakeh Steel } \\
\text { Company and Fanavaran Petrochemical Co. using Auto Regressive Distributed Lags (ARDL) } \\
\text { over the period 2008-2013. The results have indicated that there was a meaningful relationships } \\
\text { between removal of subsidies and market value of the firms. }\end{array}$ \\
\hline
\end{tabular}

Petrochemical industry

Steel industry

(c) 2015 Growing Science Ltd. All rights reserved.

\section{Introduction}

Subsidies are considered as indirect or direct payments as a financial assistance, economic points or devoting some excellences to private agencies, households and governmental firms to obtain desired objectives (Brooks, 2003). The subsidy covers all sorts of transitive payments to gain some supports for low-income as well as vulnerable communities aiming to contribute the income distribution for households or firms given by the state treasury (HooriJafari \& FarahmandPur, 2008). Government subsidy can be computed as the difference between the finished and the adjusted prices given by the government to support the target group's income. The amount of necessary subsidy is computed by subtraction of the finished price of products or services as well as the level of public buying ability (Mirzamohammadi et al., 2012). There are literally many studies on the effects of subsidy removal on economy of various countries. According to Borenstein and Bushnell (2000), deregulation on energy prices may influence on market, significantly. 
Koozehgar et al. (2014) studied the effect of welfare of self-targeted subsidies in Iran by investigating whether or not transferring one unit of subsidies devoted to the subsidized products implemented by the rich residences to the nonsubsidized products used by the poor could positively influence on social welfare using Atkinson social welfare function and stated that self-targeted subsidies could increase social welfare. The outcome of this increase influenced negatively on inequality aversion parameter, while positively influenced on the share of nonsubsidized goods in low income deciles budget.

Iravani et al. (2012) measured the impacts of recent economic reform according to subsidy removal on Iran's economy by considering some factors such as inflation, tuition fee, unemployment, consumer consumption pattern and city transportation facilities. In their survey, there was a meaningful relationship between government subsidies and transportation facilities, unemployment and consumer consumption pattern. Nevertheless, the survey did not influence on government subsidies and inflation.

Schwartz and Clements (1999) discussed the problems of defining and measuring government subsidies, examined why and how government subsidies were applied as a fiscal policy tool, discussed their general economic impacts in terms of real welfare expenses and distributional implications, appraised international empirical evidence on government subsidies, and offered options for their reform. Ahearn et al. (2006) investigated the effect of coupled and decoupled government subsidies on off-farm labor participation of US farm operators. Zhang et al. (2014) investigated the relationship among political connections, government subsidies and firm financial performance of wind and solar manufacturing companies. They reported that government subsidies, in long and short-terms, had positive effects on the financial performance of wind energy manufacturing companies. In their study, both key variables, government subsidies and an interaction term of subsidies as well as political connections, did not have meaningful impacts on the financial performance of solar energy manufacturing firms.

Sun et al. (2014) investigated the impact of biogas subsidies on household biogas energy usage in rural areas of China. They studied the problem of sample selection bias in measuring the effect of subsidies on biogas energy consumption because biogas subsidies could change the propensity for installing biogas digesters. They stated that biogas subsidies, indeed, promoted the construction of biogas digesters. They reported that the current subsidy policy did not have much impact on rural household biogas use.

López and Galinato (2007) tested the effects of subsidizing private products to the detriment of the government's supply of public products and services using some data set from the rural sector in 15 Latin American countries over the period 1985-2001. They used the information to gain some insights on separate government subsidies to private products and services from expenditures in the provision of public services. They concluded that the government's decision to subsidize maintained dramatic consequences for economic development.

Kleer (2010) performed a survey and indicated that government subsidies for research and development (R\&D) could promote projects with high returns to society. In their survey, the agency had a preference for basic research projects as they anticipate high expected social returns, while banks preferred applied research projects with high private returns.

\section{The propsoed study}

This study investigates the impacts of subsidies on the market value of listed companies in Tehran Stock Exchange in Petrochemical and Steel industries. The study selects two firms, Esfahan's Mobarakeh Steel Company and Fanavaran Petrochemical Co. using Auto Regressive Distributed Lags (ARDL) over the period 2008-2013. Mobarakeh Steel Company is an Iranian steel firm, located $65 \mathrm{~km}$ south west of Esfahan, Iran. It is the largest steel maker of Middle East \& Northern Africa region, and one of the biggest industrial complexes operating in Iran. It was commissioned after the Iranian 
Revolution in 1979 and initiated operations in 1993. It underwent major revamping during year 2000, bringing the total steel output to 7,200,000 metric tons per year in 2010. Fanavaran petrochemical company is located on the shore of Persian Gulf on west south of Iran with of 25 hectares area.

There are some advantages on ARDL method. For instance, regardless of whether the explanatory variables are I (0) or I (1), it is able to test the relationship among convergence of variables. An ARDL model can be stated as follows,

$$
\begin{aligned}
& Q(L . s) Y_{t}=\sum_{i=1}^{k} \theta_{t}\left(L, n_{t}\right) X_{i t}+\delta^{\prime} W_{t}+u_{t}, \\
& Q(L . s)=\left(1-\alpha_{1} l-\alpha_{2} l^{2}-\ldots-\alpha_{s} I^{s},\right. \\
& \theta\left(L, n_{t}\right)=\theta_{l 0}+\theta_{l 1} L+\theta_{l 2} L^{2}+\ldots+\theta_{\mathrm{ln}_{l}} L^{n_{l}},
\end{aligned}
$$

where $L$ represents the first order time delay operator with $L X_{t}=X_{t-1}, y_{t}$ represents a dependent variable, $X_{i t}$ denotes the vector of independent variables, $K$ is the number of explained variables, $n_{1}, n_{2}, \ldots n_{t}$ represent the number of optimum interruptions for independent variables and, $S$, denotes the number of optimum interruptions for dependent variable. Besides, $w_{t}$ is associated with the vector of deterministic variables such as the intercept, seasonal variables, time or exogenous variables defined and estimated using ordinary least square (OLS) for all values for $s=0,1,2, \ldots . d, n_{t}=0,1,2, \ldots . d$, $i=0,1,2, \ldots k$. In other words, $(d+1)^{k+1}$ numbers of ARDL models need to be estimated where the maximum number of interruptions is stated by $d$ and for all techniques we have $t=d+1, \ldots n$. Error correction model fits ARDL model is as follows,

$$
\Delta y_{i}=-Q(L, \hat{s}) E C T_{t-1}+\sum_{i=1}^{k} \theta_{l 0} \Delta x_{i t}+\delta^{\prime} \Delta w_{t}-\sum_{j=1}^{\hat{s}-1} Q^{*} \Delta y_{t-j}-\sum_{i=1}^{k} \sum_{j-1}^{\hat{n} i-1} \theta^{*} i j \Delta x_{t, i-j}+u_{t}
$$

where $\Delta w_{t}, \Delta x_{i t}, \Delta y_{t}$ denote vectors of deterministic, independent and dependent variables, respectively. Finally, $Q^{*}, \theta^{*} i j$ are error correction coefficients.

There are two types of variables for the proposed study of this paper,

1. Industry index performance (growth): This index is measured for each industry separately. In this study, the indicator for the cement industry and the automotive industry and using information from companies listed in Tehran Stock Exchange for the period 2008-2013 have been implemented.

2. The overall market index: This index indicates positive and negative market trends and also gives a mean of comparison with the past. The study chooses two firms, Esfahan's Mobarakeh Steel Company and Fanavaran Petrochemical Co over the period 2008-2013. We anticipate that as the economy grows, overall index market could also increase and industry sector also increases, too. This study reported the results of three models; namely Dynamic, Error-Correction and Long-run of subsidy removal on market.

\section{The results}

\subsection{Petrochemical Industry}

We first study the impacts of subsidy removal on Petrochemical industry. Table 1 shows the results of ADRL dynamic. 


\section{Table 1}

The summary of the results of ADRL dynamic to examine the effects of subsidy removal in Petrochemical industry

\begin{tabular}{llccc}
\hline Row & & Coefficient & t-value & Sig. \\
\hline 1 & Intercept & 5.87 & 4.33 & 0.000 \\
2 & Petrochemical industry index & -0.503 & 5.29 & 0.000 \\
\hline
\end{tabular}

R-Square $=0.75$, F-value $=12.13$, Sig. $=0.000, \mathrm{D}-\mathrm{W}=2.70$

According to the results of Table 1, both coefficients are meaningful when the level of significance is one percent. R-Square value is 0.75 , which indicates that the independent variable could describe $79 \%$ of the changes on dependent variable. In addition, F-value is statistically meaningful, which means the relationship is linear and Durbin-Watson value is equal to 2.7, which means there is no auto-correlations among residuals. As we can expect from the results of Table 1 , the increase on energy prices as a results of subsidy removal has influenced negatively on the performance of Petrochemical industry. Table 2 demonstrates the results of ADRL Correction-Error

Table 2

The summary of the results of ADRL Correction-Error

\begin{tabular}{llccc}
\hline Row & & Coefficient & t-value & Sig. \\
\hline 1 & Intercept & 5.87 & 11.56 & 0.000 \\
2 & Petrochemical industry index & -0.50 & 5.87 & 0.002 \\
3 & Ecm (-1) & -0.623 & -11.9 & 0.000 \\
\hline
\end{tabular}

The results of ADRL correction-Error model are similar to Table 1, which means energy subsidy has negative effect on Petrochemical industry. Moreover, Table 3 shows the results of Long-run of subsidy removal on market, whose results are somewhat consistent with Dynamic and Correction-Error models. In our survey, over the long term, an increase on energy prices had negative consequences on Petrochemical industry.

Table 3

The summary of the results of ADRL Long-run of subsidy removal on Petrochemical industry

\begin{tabular}{llccc}
\hline Row & & Coefficient & t-value & Sig. \\
\hline 1 & Intercept & 0.055 & 5.92 & 0.000 \\
2 & Petrochemical industry index & -0.8 & 4.62 & 0.000 \\
\hline
\end{tabular}

\subsection{Steel Industry}

We next investigate the effects of subsidy removal on auto industry. Table 4 presents the results of ADRL dynamic.

\section{Table 4}

The summary of the results of ADRL dynamic on the effects of energy subsidy removal on Steel industry

\begin{tabular}{llccc}
\hline Row & & Coefficient & t-value & Sig. \\
\hline 1 & Intercept & 5.81 & 11.45 & 0.000 \\
2 & Steel industry index & 0.188 & 4.18 & 0.002 \\
\hline R-Square & $=0.78$, F-value = 15.10, Sig. $=0.000$, D-W = 3.146 & & &
\end{tabular}

According to the results of Table 4, both coefficients are meaningful when the level of significance is one percent. R-Square value is equal to 0.78 , which shows the independent variable describes approximately $78 \%$ of the changes on dependent variable. Moreover, F-value is statistically meaningful, which means the relationship is linear and Durbin-Watson value is equal to 3.146. As we can see from the results of Table 4, the increase on energy prices as a results of subsidy removal influenced positively on the performance of auto industry. Table 5 shows the results of ADRL Correction-Error. 
Table 5

The summary of the results of ADRL Correction-Error on the effects of subsidy removal on Steel industry

\begin{tabular}{llccc}
\hline Row & & Coefficient & t-value & Sig. \\
\hline 1 & Intercept & 5.81 & 11.45 & 0.000 \\
2 & Steel industry index & 0.188 & -4.18 & 0.002 \\
3 & Ecm (-1) & -0.53 & -9.77 & 0.000 \\
\hline
\end{tabular}

The results of ADRL correction-Error model are similar to Table 4, which means energy subsidy maintains positive effect on Steel industry. Finally, Table 6 presents the results of Long-run of subsidy removal on market, whose results are consistent with Dynamic and Correction-Error models. In our survey, over the long term, an increase on energy prices has positive consequences on Steel industry.

\section{Table 6}

The summary of the results of ADRL Long-run

\begin{tabular}{llccc}
\hline Row & & Coefficient & t-value & Sig. \\
\hline 1 & Intercept & 0.668 & 6.14 & 0.000 \\
2 & Auto industry index & 0.34 & 3.58 & 0.002 \\
\hline
\end{tabular}

\section{Discussion and conclusion}

In this survey, we have presented a study to examine the effects of energy prices on the performance of Petrochemical and Steel industries. Using different ADRL models, the study has determined that the subsidy removal had negatively influenced on Petrochemical industry and positively influenced the Steel industry. The results of this study are somewhat consistent with other findings reported by Worrell et al. (1997), Lee and Ni (2002) and Price et al. (2002) in Steel industry. The results are also consistent with findings of Worrell et al. (2000) and Pillay and Fendley (1995) in Petrochemical industry.

\section{Acknowledgement}

The authors would like to thank the anonymous referees for constructive comments on earlier version of this paper.

\section{References}

Ahearn, M. C., El-Osta, H., \& Dewbre, J. (2006). The impact of coupled and decoupled government subsidies on off-farm labor participation of US farm operators. American Journal of Agricultural Economics, 88(2), 393-408.

Borenstein, S., \& Bushnell, J. (2000). Electricity restructuring: deregulation or reregulation. Regulation, 23, 46.

Brooks, A. C. (2003). Do government subsidies to nonprofits crowd out donations or donors?. Public Finance Review, 31(2), 166-179.

HooriJafari, H., \& FarahmandPur, B. (2008). Energy loans and its effect on the different parts of economics. Journal of Energy Economics Surveys, 2, 162-178.

Iravani, M., Kelari, B., Taghipour, F \& Tajbakhsh, G. (2012). A social work study on measuring the impact of government subsidies reform on economy. Management Science Letters, 2(8), 2917-2922.

Koozehgar, P., Pourghaz, G \& Ortaboulagi, S. (2014). The impact of self-targeted subsidies on social welfare in Iran. Management Science Letters, 4(7), 1531-1536.

Kleer, R. (2010). Government R\&D subsidies as a signal for private investors. Research Policy, 39(10), 1361-1374.

Lee, K., \& Ni, S. (2002). On the dynamic effects of oil price shocks: a study using industry level data. Journal of Monetary Economics, 49(4), 823-852. 
López, R., \& Galinato, G. I. (2007). Should governments stop subsidies to private goods? Evidence from rural Latin America. Journal of Public Economics, 91(5), 1071-1094.

Mirzamohammadi, S., Ghaderi, F \& Ardakani, M. (2012). Assessing the effects of removing of energy subsidies on urban passenger transportation within the city of Tehran based on a system dynamics approach. Management Science Letters, 2(6), 2125-2134.

Pillay, P., \& Fendley, K. A. (1995). The contribution of energy efficient motors to demand and energy savings in the petrochemical industry. Power Systems, IEEE Transactions on, 10(2), 1085-1093.

Price, L., Sinton, J., Worrell, E., Phylipsen, D., Xiulian, H., \& Ji, L. (2002). Energy use and carbon dioxide emissions from steel production in China. Energy, 27(5), 429-446.

Schwartz, G., \& Clements, B. (1999). Government subsidies. Journal of Economic Surveys, 13(2), 119148.

Sun, D., Bai, J., Qiu, H., \& Cai, Y. (2014). Impact of government subsidies on household biogas use in rural China. Energy Policy, 73, 748-756.

Worrell, E., Price, L., Martin, N., Farla, J., \& Schaeffer, R. (1997). Energy intensity in the iron and steel industry: a comparison of physical and economic indicators. Energy Policy, 25(7), 727-744.

Worrell, E., Phylipsen, D., Einstein, D., \& Martin, N. (2000). Energy use and energy intensity of the US chemical industry. Lawrence Berkeley National Laboratory.

Zhang, H., Li, L., Zhou, D., \& Zhou, P. (2014). Political connections, government subsidies and firm financial performance: Evidence from renewable energy manufacturing in China. Renewable Energy, 63, 330-336. 